\title{
Russian Regions in the Acute Phase of the Coronavirus Crisis: Differences from Previous Economic Crises of the 2000s
}

\author{
N. V. Zubarevich ${ }^{a, b}, *$ and S. G. Safronov ${ }^{a, * *}$ \\ ${ }^{a}$ Lomonosov Moscow State University, Faculty of Geography, Moscow, 119991 Russia \\ ${ }^{b}$ Russian Presidential Academy of National Economy and Public Administration, Moscow, 119571 Russia \\ *e-mail: nzubarevich@gmail.com \\ **e-mail: saffff@mail.ru
}

Received June 27, 2020; revised June 27, 2020; accepted July 18, 2020

\begin{abstract}
The article examines the dynamics of the socioeconomic development of the Russian regions and the state of their budgets in the acute phase of the coronavirus crisis in April-May 2020. Differences in the rate of decline are revealed, due not only to the severity of quarantine measures, which affected the consumption indicators, but also the structure of the regional economy, which strongly influenced the industrial production dynamics and budget revenues. The rapid increase in the level of registered unemployment in almost all regions is due to the impact of quarantine restrictions on the market services sector, which is the most developed in large cities, as well as institutional measures (increase in the size of benefits and streamlined registration). The regional dynamics of the main indicators during the three crises of the 2000s are compared and significant differences are revealed in the distribution of regions by the rate of decline. The regional profile of each crisis was different due to its factors, risk zones, duration, and depth of the decline. The coronavirus crisis is aggravated by the fact that in most regions, the decline of the previous crisis in 2015 has not yet been compensated, which may lead to a protracted recovery from the 2020 crisis.
\end{abstract}

Keywords: Russian regions, crisis, industrial dynamics, retail trade dynamics, paid services dynamics, unemployment rate, regional budgets

DOI: $10.1134 /$ S2079970520040115

\section{INTRODUCTION AND FORMULATION OF THE PROBLEM}

Since the late 2000s, Russia has been enduring through third crises. Two are global (the 2008-2009 economic crisis and 2020 coronavirus crisis). However, the crisis that began in December 2014 was caused not only by global, but also by internal factors, primarily, stagnation of the economy, which began back in 2013.

Each crisis in Russia differs by the factors influencing it, in depth and duration, speed of exit, and sectors of the economy most severely affected. There are differences in the regional projection (geography) of different crises, but they are much less studied.

Research on individual crises is necessary but insufficient. From the scientific standpoint, comparative analysis of the regional projection of the Russian crises of the 2000s is more interesting, but such publications could not be found. Previous studies by the authors of this article show that the differences are very significant, both in socioeconomic dynamics and in the state of regional budgets. Reinterpreting Leo Tolstoy's phrase, we can say that regions, like families, are "unhappy in their own way" during various crises.
The article poses two tasks. The first is a detailed analysis of the regional dynamics of the coronavirus crisis in its acute phase (April and May 2020). The second is a comparison of the regional projections of the three crises (2009, 2015, and 2020) and identification of their regional specifics based on the dynamics of socioeconomic and budget indicators.

\section{REVIEW OF EARLIER STUDIES}

The first studies on "crisis regionalism" in Russian geography were devoted to the former socialist countries of Eastern Europe, including Russia, that embarked on the transition to a market economy [11]. It examined the influence of the structure of the regional economy on the course and prospects of economic reforms, revealed an increase in regional inequality, and considered the relationship between two aspects of the crisis: economic and social. Even before the end of the transformational crisis in Russia, the same authors showed the importance of the sectoral structure of the economy and the trend of growth in regional inequality [12]. It is the specialization of the regional economies that led to territorial shifts in 
industry and an increase in its concentration along the Taimyr-Yamal-Ural-Volga axis.

The studies by the authors of this article were carried out after the end of the transformational crisis; they also showed that regional differences in the depth of the recession in the 1990s were primarily due to the structure of the economy of federal subjects and global competitiveness of specialized industries. In regions with export industries (oil and gas production; since the mid-1990s, metallurgy, petrochemistry, production of mineral fertilizers, etc.), the decline was less severe than in regions with less competitive machinery industry and light industry, as well as in regions of late industrialization, which include the less developed republics [16]. The long transformational crisis of the 1990s influenced the development of Russian cities, and their differentiation increased significantly [13].

Regional projections of the 2000s crises were less well studied, perhaps because the crises were less profound and less prolonged. For the global crisis that manifested itself in Russia at the end of 2008, the sectoral factor was also the most important; the crisis primarily hit industrial production (a decline of $11 \%$ in 2009) and employment. Earlier and more strongly, it affected metallurgical industries with a high share of exports. The short-term, although strong decline in oil and gas prices had little effect on the dynamics of oil and gas specialization regions; in most of them, industrial growth continued. The second problem area was Russian machinery industry and regions with this specialization; their problems are associated with low competitiveness, and therefore, the impacts of the crisis for them, as a rule, have been more painful. It was in metallurgical and machinery industry specialization regions that the maximum increase in unemployment was noted, as well as a drop in budget revenues due to a strong decrease in profit tax revenues [3]. This crisis was characterized by a rapid decline in the economy, but also by its fairly rapid recovery by 2011 . It is also important to note that during the 2009 crisis, the federal authorities sharply increased support for federal subjects-the transfers to the regions increased by a third.

The geography of the 2009 crisis when it was in full swing was also considered in [14]. The authors tried to assess the potential and prospects of regions passing through a crisis of a different nature, associated with the cyclical nature of the global economy. They suggested that the most likely result would be a "flattening," a decrease in interregional inequality due to weakening and reduction of the number of leading regions and expansion of the semiperiphery. As one of the few stabilizing factors, the authors identified the precrisis expansion of the suburban spaces of strong urban agglomerations. However, there were no significant changes in regional inequality during this crisis [4], because the recovery was fairly rapid.
The crisis that began in December 2014 and continued, according to various estimates, for 2-3 years, was completely different. The global factor was a short-term, albeit strong drop in oil prices and devaluation of the ruble, but the underlying causes of the crisis were institutional. The economy nearly ceased growing back in 2013 due to institutional barriers caused by an unfavorable business climate; in 2014, sanctions became an additional negative factor [5]. The pain points of this crisis were also different: a strong decline in investment (including foreign direct investment, almost tenfold), household income, and consumption. Industrial production declined insignificantly in 2015 (by 2\%). The crisis proved protracted, and the most problematic indicators did not recover even in 2019, if we take into account the dynamics from the initial year of recession. In 2019, the investment were 3\% lower than the 2013 level; housing construction and retail trade, by $8 \%$ of the 2015 and 2014 levels, respectively; disposable household incomes were lower than the precrisis level by $7 \%$ [6]. Only industry showed relatively stable growth (10\% compared to 2014) due to higher prices for Russian exports and steady growth in the food industry due to antisanction measures. Thus, most Russian regions on the eve of the coronavirus shock had not compensated for the drop in investment, household income, and consumption that occurred during the previous crisis. In addition, support from the federal budget during the 2015 crisis was very limited, and transfers to regions in 2015 and 2016 barely increased; significant growth began only in 2018 and 2019 (over $20 \%$ ) and was associated with the electoral cycle and other reasons.

The coronavirus crisis that began in 2020 is also global. Its uniqueness lies in the large-scale restrictions on mobility of the population (quarantines) and suspension of most of the service sector, as well as many industrial enterprises. Quarantines led to a slowdown in economic activity, a decrease in demand, and a sharp drop in the price of oil and other products of the Russian export industries. In Russia, the acute phase of the crisis occurred in April-May. The severity and duration of restrictions in Russian regions varied, from the maximum in the Moscow agglomeration to relatively weak, e.g., in Tver oblast and the republics of southern Siberia.

The impact of the coronavirus crisis on the Russian economy, employment, living standards, and regional budgets has been monitored by the Higher School of Economics (HSE) and Russian Presidential Academy of National Economy and Public Administration (RANEPA). Model calculations of the decline in household incomes and growth in the poverty level are performed in [17], as well as assessments of the impact of support measures implemented by the Russian authorities [15], but all this was calculated for the country as a whole. Monitoring by RANEPA and the Gaidar Institute examined the scale of the decline in 
regional budgets revenues in April 2020 [10]; such an analysis was also done by the HSE Development Center [1]. Monitoring by the Institute for Social Analysis and Forecasting (INSAF) of RANEPA represents a more comprehensive regional analysis of the crisis dynamics of socioeconomic and budget indicators, assessing the differentiation of regions by the rate of decline in the acute phase of the crisis in April [9]. The results of this analysis, carried out by one of the authors of this article, are used in this article. The article is also supplemented with the dynamics for May 2020 for industrial production and the unemployment rate.

In addition, one of the authors of the article analyzed the risks of the coronavirus crisis for employment and regional budgets, suggesting that the risks of rising unemployment are maximum for large cities with the highest share of employment in the market services sector [7]. O.V. Kuznetsova also considered the risks of the new crisis for regions with high informal employment and, at the same time, with increased employment in the more stable public services sector. The article analyzes the market services sector in regions and concludes that it is necessary to reduce employment in simple services, primarily in trade [8].

\section{MATERIALS AND METHODS}

The study uses monthly Rosstat data on the dynamics of socioeconomic indicators reflecting crisis phenomena: industrial production, retail trade, paid services, overall unemployment level (according to the ILO methodology) and registered unemployment. Obviously, we need to supplement these with the dynamics of household incomes and the poverty level, but this cannot be done for the latest (coronavirus) crisis, because data on the disposable household incomes since 2019 are published only quarterly. Regional data for the second quarter of 2020, when the crisis-related decline in household incomes due to quarantine was maximum, will be available only by the beginning of September, and data on the poverty level, even later and only for the enitre year.

Monthly data make it possible to identify the "bottom" of the crisis; this was done for each indicator for the two previous crises in 2009 and 2015. The calculations used the dynamics of the cumulative total for the period from the beginning of the year to the month the bottom was reached to the same period of the previous year. The crisis-related recession in 2020 was analyzed differently: data were used only for April and May, since it was in these two months that the recession was strongest due to quarantine restrictions. The differences in the methodological approaches are due to the different natures of the crises and duration of the recession: in the 2009 and 2015 crises, the recession was protracted, lasting most of the year, and in 2020, it had an avalanche character due to the quarantine; therefore, the total dynamics for January-April or January-May are unsuitable for 2020: it hides the scale of the recession.

The second source is data from the Federal Treasury on the execution of consolidated regional budgets on a monthly cumulative basis. Analysis of monthly data showed that the bottom in 2009 was passed by the end of August, so the dynamics for January-August was taken for the same period of 2008. In 2015, there was no crisis-related decline in budget revenues, but for comparability, the same period was used (January-August). In 2020, the crisis-related recession had an avalanche character precisely in April due to the quarantine; therefore, for our analysis, the indicators were calculated only for this month and not for January-April.

Once again, we note that the use of different methodological approaches to selecting the indicators results from the posed task of assessing the depth of recession in regions during three crises with different durations, speeds, and depths of decline influenced not only by economic, but also institutional factors. During the 2009 and 2015 crises, the decline was gradual and relatively protracted; during the coronavirus crisis, it was rapid, so only data for April and May can reveal its depth.

The paper uses simple analysis methods: histograms of the distribution of regions by rate of decline for socioeconomic and budget indicators and maps of the dynamics of indicators that most clearly reflect the territorial differences of crises. The authors deliberately abandoned econometric methods, understanding the multifactorial nature of the crisis-related impact on regions and the impossibility of adequately explaining the results of econometric calculations. The experience of econometric measurements shows the difficulties of their application to such a contrasting country as Russia. There are many examples; we will give only one-an attempt to assess the GRP dynamics based on the level of regional income inequality [2]. The review of studies in the United States and Western Europe given in this paper demonstrates the ambiguity of the results, and the positive, although short-term effect of the influence of inequality on economic growth in the regions for Russia, discovered by the authors of this paper, is not accompanied by an analysis of the nature of this relatonship and is certainly unable to explain changes in the course of any crisis.

\section{RESULTS}

\section{Trends in the Coronavirus Crisis in Regions}

The acute phase (April and May 2020) was the most painful for paid services; in April 2020, they decreased by $38 \%$ compared to the same period in 2019. The main reason is the quarantine, related restrictions, and suspension of the activities of many 
service-providing organizations. In addition to quarantine restrictions, in the face of decline in incomes, Russians began to save on housing and communal services. During the crisis, the federal authorities decided to suspend penalties for late payments for housing and communal services, which led to a rapid increase in nonpayments to supplying organizations (in April and May, they reached RUB 230 bln) Regional differences in the decline in paid services are significant (from 20 to $-50 \%$ ), but their consumption declined strongly everywhere. The worst dynamics are in federal subjects with stricter quarantine restrictions (Moscow, Moscow oblast, St. Petersburg, Sverdlovsk oblast, Sakha Republic (Yakutia)). A strong decline was also noted in the republics of the North Caucasus, where nonpayments for housing and communal services were significant even before the crisis, as well as in southern regions (Krasnodar and Stavropol krais, Republic of Crimea, Sevastopol) due to restrictions on opening of the tourist season. In addition, the recession most likely reflects the disappearance of small businesses; in the south, they mainly provide paid services.

The second impact of the quarantine and restrictions is against retail: its turnover in April decreased by $23 \%$ versus April 2019; in two-thirds of regions, from 15 to $38 \%$ (Fig. 1). Due to strict quarantine measures, Moscow and St. Petersburg have been hit harder (a decline of $29-31 \%$ ). The stronger decline in retail trade turnover in most regions of the Southern and North Caucasian federal districts (by 30-37\%) is due to the worse survival opportunities for small trade business, which prevails in the south, and its partial withdrawal into the shadow economy. Compared to retail chains, small businesses are less robust and more vulnerable. Prospects for the recovery of retail trade and paid services will be clear only at the end of two or three quarters; they depend on the depth of the decline in household income and the ability of businesses to adapt to the changed conditions.

Trade and other paid services are most developed in the largest urban agglomerations and large regional centers, where the effective demand of the population is higher; therefore the coronavirus crisis has a different geography compared to the two previous crises: it hit large cities with a more modernized consumption structure and maximum share of employed in the market services sector.

The recession of industry started in April (-7\%) and accelerated in May (-10\%). In April, production fell in 55 regions, and in May, in 59; i.e., the decline was not widespread, unlike for market services (see Fig. 1). Two groups of regions had a stronger decline in May (by 12-26\%): export specialization regions-oil production (the Nenets and Khanty-Mansi autonomous okrugs, Komi and Tatarstan republics, Tomsk oblast), diamond production (Sakha Republic (Yakutia)), nonferrous metallurgy (Krasnoyarsk krai), as well as regions with industries working mainly for the domestic market: automotive (Samara, Ulyanovsk, Nizhny Novgorod, Kaliningrad oblasts), jewelry (Kostroma oblast), tires and oil products (Omsk oblast). The main reason for the growing recession in May is no longer the quarantine, but a strong contraction of global and domestic demand for Russian industrial products; this is a longer-term factor.

The lag in regional statistics hinders assessment of the two most pressing problems - the rate of decline in disposable household incomes and growth of underemployment. Already in the first quarter of 2020, the number of idle workers increased by $1.5-3$ times in the two largest urban agglomerations of the country and in a number of industrial regions (Perm krai, Samara and Kemerovo oblasts). In the second quarter, the level of underemployment will inevitably increase due to quarantine measures, which have limited the work of the service sector, and an increase in the downturn in industry, so there will be much more problem regions.

Only by autumn will we be able to assess the ratio of the two forms of adaptation of regional labor markets to the crisis: the growth of underemployment (with a decrease in wages) and growth of unemployment. In May 2020, the unemployment rate according to the ILO methodology increased in Russia as a whole to $6 \%$ compared to $4.6 \%$ at the beginning of the year and reached $4.5 \mathrm{mln}$ people (at the beginning of the year, $3.5 \mathrm{mln}$ people). The growth is relatively small, but it should be borne in mind that population surveys on employment problems (PSEP) were carried out by Rosstat during the quarantine period by phone (a change of format may affect the result). In addition, many workers placed on unpaid leave and other parttime regimes hoped to return to their jobs after the quarantine and did not identify as unemployed. A more significant increase in unemployment according to the ILO methodology based on data for MarchMay (by more than two percentage points compared to the first quarter of 2020) occurred in a small number of regions: in a number of less developed republics (Tyva, Dagestan, Khakassia, Chuvash Republic), in problem oblasts of the Center (Vladimir, Ivanovo, and Oryol olbasts), among more developed regions-in Yaroslavl, Tomsk oblasts, Krasnoyarsk krai.

The growth of registered unemployment proved more adequate indicators. The decision by the federal authorities to raise the amount of unemployment benefits to the subsistence level in the region (in Moscow, even higher), along with simplification of the procedure for registering with employment services, was an incentive for many who lost their jobs to apply for benefits. According to the Ministry of Labor, as of midJune 2020, the number of people who applied to employment services reached $2.5 \mathrm{mln}$ (3.5 times higher than in February). The registered unemployment rate rose from $1 \%$ at the end of March to $2.9 \%$ at the end of May. The most significant growth (four to 

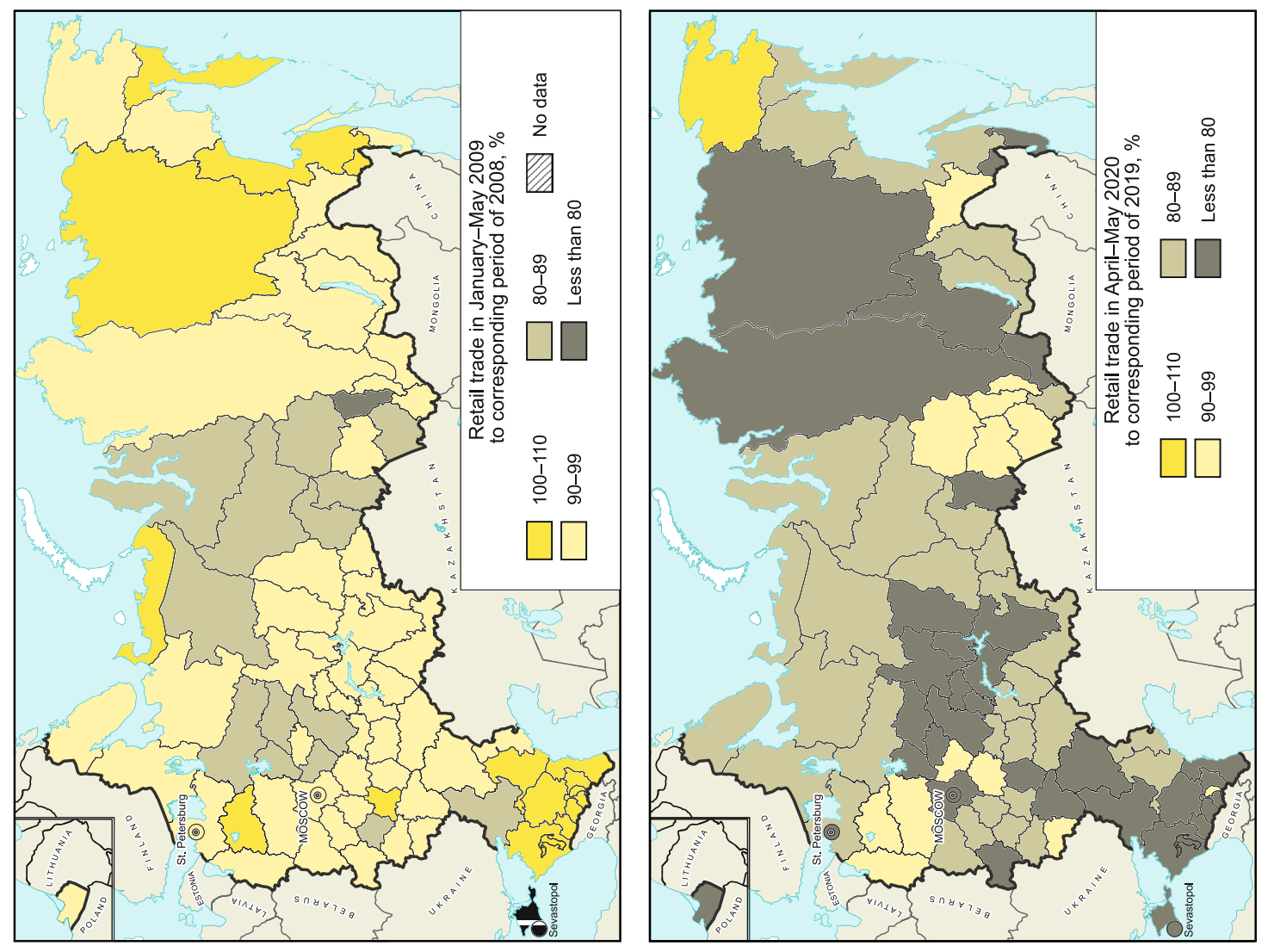

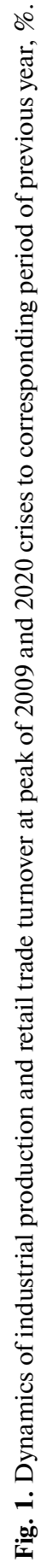
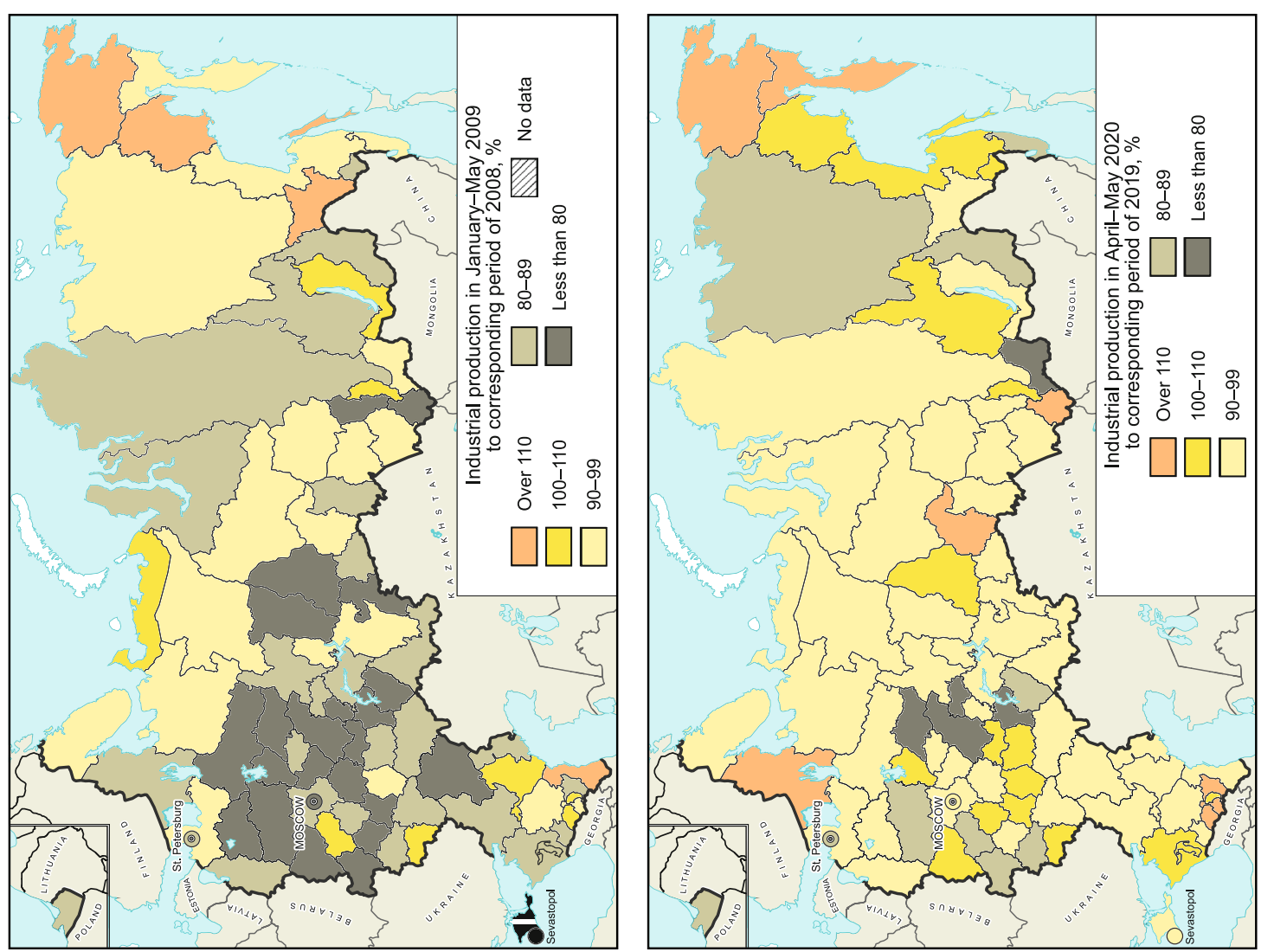
five times) was observed in regions with an initially low level of registered unemployment: Moscow and Moscow oblast, St. Petersburg and Leningrad oblast, the Republic of Tatarstan, Tyumen oblast, Krasnodar krai, as well as regions with a developed automotive industry (Nizhny Novgorod, Ulyanovsk, Kaliningrad, Kaluga oblasts), and problem oblasts of the Center (Ivanovo, Kostroma, and Bryansk oblasts). The absolute increase in the number of registered unemployed was maximum in large and developed regions (Moscow, Moscow oblast, St. Petersburg, the republics of Tatarstan and Bashkortostan, Sverdlovsk oblast) with more significant employment in the services sector.

The growth of registered unemployment is minimum in the remotest Far Eastern regions (Chukotka Autonomous Okrug, Sakhalin and Magadan oblasts, Kamchatka krai), where market services are less developed and industry has not fallen into the risk zone. Another group is the underdeveloped republics with an initially maximum level of registered unemployment (Republic of Ingushetia and Chuvash Republic); this is an effect of the base.

The crisis-related recession of budget revenues in regions manifested itself in full force only in April. Tax and nontax revenues decreased by RUB 350 bln, almost $3 \%$ of total budget revenues in 2019. According to forecasts of the HSE Development Center and Accounting Chamber, the shortfall in revenues of regional consolidated budgets for the entire of 2020 may amount to RUB $1.3 \mathrm{tln}$. This is $10 \%$ of total revenues, while in April, almost 3\% was already lost.

Own (tax and nontax) revenues of regional consolidated budgets decreased in April by almost 30\%, including profit tax, by 29\%; personal income tax (PIT), by $19 \%$; property, by $44 \%$; small business taxes (on total revenue), by $40 \%$. Own budget revenues decreased in 81 out of 85 regions, most of all (by 35$60 \%$ ) in the regions of oil and gas and metallurgical specialization (Yamalo-Nenets Autonomous Okrug; Perm and Krasnoyarsk krais; the republics of Komi, Tatarstan, and Bashkortostan; Astrakhan, Vologda, Sakhalin, Murmansk, Sverdlovsk, Kemerovo, and Orenburg oblasts). In the context of the global crisis, the export orientation of their economies led to a sharp drop in profit tax (Fig. 2). Own revenues of Moscow's budget decreased by a third, and by $30 \%$ in St. Petersburg. The decline in total budget revenues in April was less severe, by $21 \%$, as the federal authorities increased their assistance to the regions (transfers) by a third (see Fig. 2).

For the labor market, the dynamics of PIT is most indicative; it reflects changes in wages at enterprises and organizations that pay this tax. The dynamics of PIT receipts $(-19 \%$ in April) is much worse than the average monthly accrued wages in April provided by Rosstat $(-2 \%$ in real terms and $+1 \%$ in nominal terms by April 2019). Such discrepancies can partly be explained only by the fact that Rosstat calculates wages for large and medium-sized enterprises and organizations, and during the coronavirus crisis, small businesses were hit hardest.

In more than ten industrial regions, the dynamics of PIT is worse than the average due to increased underemployment (idle time, unpaid leave, etc.) and a decrease in wages for this reason (the Udmurt Republic and Perm krai, by 34-37\%; Tyumen oblast, 32\%; the Republic of Tatarstan and Chuvash Republic, and Vladimir, Yaroslavl, Lipetsk, Nizhny Novgorod, Kirov, Astrakhan, and Kemerovo oblasts, by 23$28 \%$ ). There, the decline in PIT is due to a strong drop in demand for industrial products, not just quarantine restrictions. The decrease in PIT revenues to the budgets of the Moscow agglomeration and St. Petersburg $(-23$ to $-24 \%)$, as well as Krasnodar krai $(-28 \%)$ is due to the strict quarantine and suspension of activities of a significant number of enterprises and the market services sector (see Fig. 2). A stronger decline in PIT against a moderate increase in unemployment shows that in the coronavirus crisis, the main form of adaptation remains the massive transfer of workers to part-time employment (idle time, unpaid leave, etc.) and a decrease in wages. Dismissals during the crisis are much less frequent due to the rigidity of the Labor Code and pressure from the authorities on employers.

In general, the April 2020 crisis hit the budgets of resource-export industrial regions and the largest urban agglomerations harder. The budgets of highly subsidized regions suffered the least due to the stable allocation of transfers and insignificant share of profit tax in their revenues. The duration of the decline in tax revenues of regional budgets can be judged only from the data for May-June.

\section{Comparison of Regional Projections of the Three Crises}

The histograms of the distribution of regions by the dynamics of socioeconomic indicators show clear differences between the three crises of the 2000s (Fig. 3). The industrial decline was highest in 2009, and the median values of the decline in regions amounted to $85-95 \%$ of the 2008 level. The map of the decline during this crisis shows its scale and the worst dynamics in the machinery-industry and metallurgical regions (see Fig. 1). The histogram of the coronavirus crisis (average data for April and May) by the distribution of regions is still closer to the 2015 crisis, when the industrial decline was minimum and not in all federal subjects; however, a shift to the worse is noticeable.

In retail trade, the coronavirus crisis was most severe due to the institutional factor (quarantine); the "blurred" distribution of regions shows significant regional differences in the severity of restrictions. During the 2015 crisis, the negative dynamics of retail trade was due to general economic factors (devaluation of the ruble and declining household incomes), 


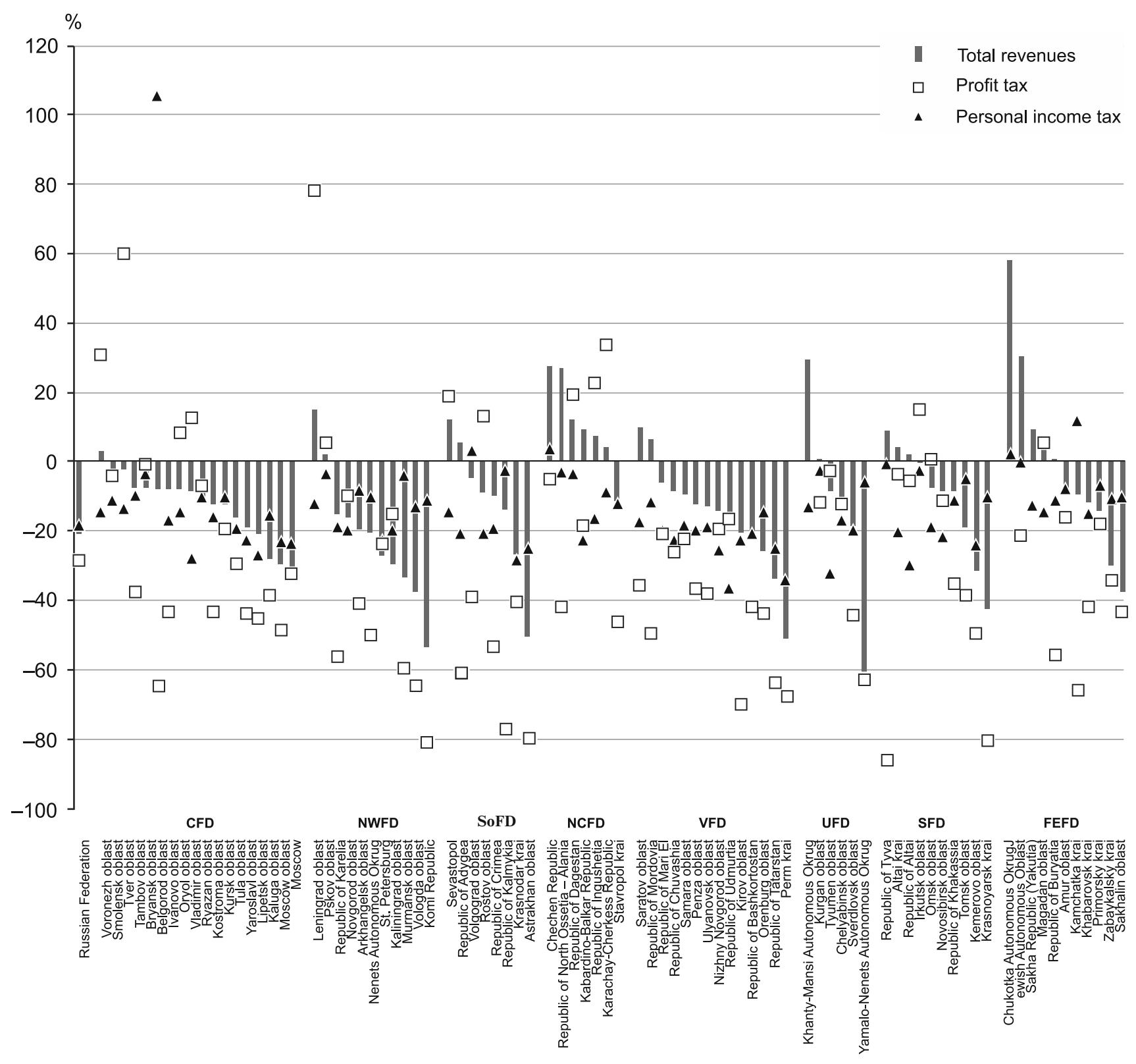

Fig. 2. Dynamics of revenues of regional consolidated budgets in April 2020 versus April 2019, \%, (federal subjects ranked within federal districts). Federal Districts: CFD-Central, NWFD-Northwestern, SoFD-Southern, NCFD-North Caucasian, VFD-Volga, UFD-Ural, SFD-Siberian, FEFD-Far Eastern. Calculated based on Federal Treasury data.

the distribution was more concentrated, and the decline in most regions was $5-12 \%$. The 2009 crisis affected retail trade much more weakly; in most regions, the decline was insignificant or absent altogether (see Fig. 1). Rosstat did not note a drop in household income in 2009 for the country as a whole, although in about 30 regions with a strong industrial recession, which led to an increase in unemployment and underemployment, there was a clear decline, as indicated by the retail trade dynamics.
In paid services, the coronavirus crisis manifested itself the most strongly, since in all previous crises there had been no institutional restrictions. With a significant range of differences in the dynamics of the recession of the regions (by $15-50 \%$ ), the distribution is still denser than in retail trade, since paid services activity was suspended in almost all regions, but with different degrees of severity. Also important is the contribution to the negative dynamics from nonpayment for housing and communal services, which has grown everywhere, but in different ways. The two previous 

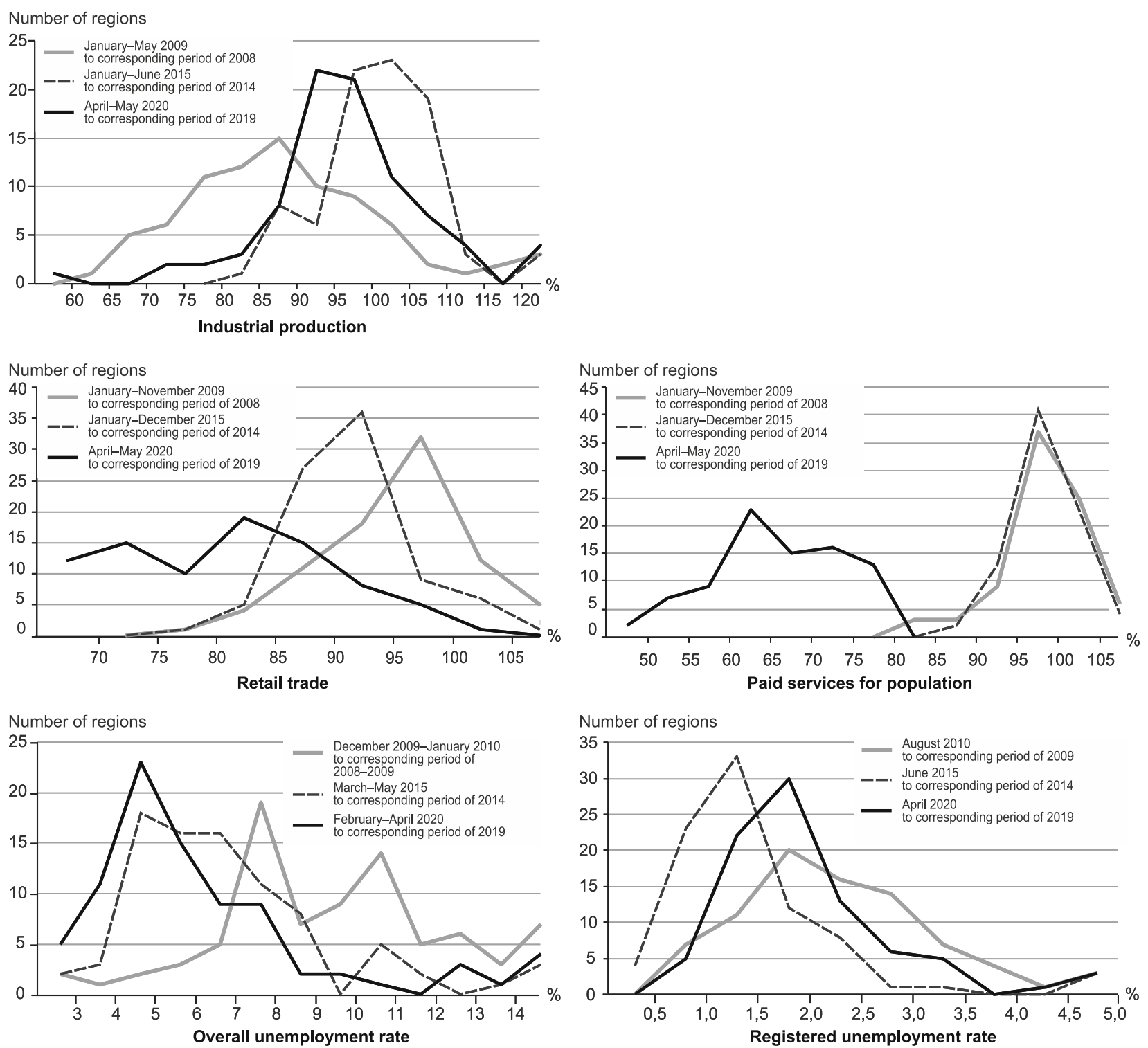

Fig. 3. Distribution of regions by dynamics of main socioeconomic indicators at peaks of crises, number of regions. Compiled based on Rosstat data.

crises hardly differ in terms of the distribution of regions; paid services were not affected.

The crisis indicators of the unemployment rate, measured according to the ILO methodology (total unemployment), were also different. The worst for regions was 2009; more than half of them had indicators of $7-11 \%$. The reason was the severe industrial crisis. The 2015 crisis did not affect the stable distribution of regions by the level of unemployment that developed in the 2010s. Most of them retained low values; a number of semidepressed and remote regions demonstrated an increased level even before the crisis, while underdeveloped republics showed a high level. In March-May 2020, the distribution of regions did not differ significantly from the previous crisis. Can it be argued that regional labor markets in the $2010 \mathrm{~s}$ stopped responding to crises by increasing unemployment, while underemployment and lower wages became the dominant means of adaptation?

This statement is incorrect if the institutional environment changes. During the 2009 crisis, the level increased and the histogram was similar to a stretched, but normal distribution, since regional labor markets were affected by the crisis in different ways. The machinery-industry and metallurgical regions were hit hardest, which resulted in a "hump" with an unemployment rate of $2-3 \%$. During this crisis, the amount of benefits increased, although not as significantly and with restrictions based on length of employment and wages. During the 2015 crisis, the 

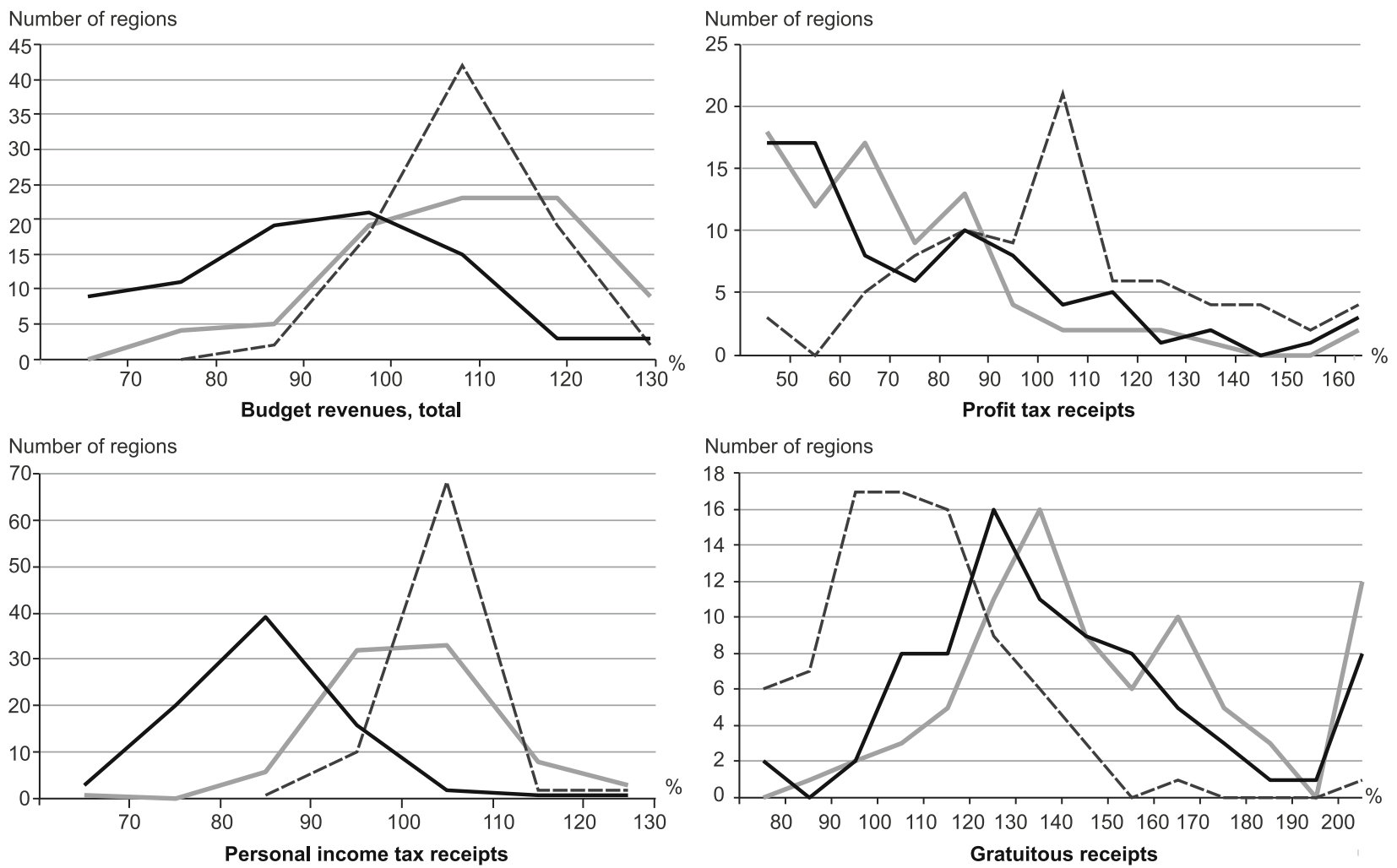

January-August 2009 to corresponding period of 2008
- January-August 2015 to corresponding period of 2014
April 2020 to corresponding period of 2019

Fig. 4. Distribution of regions by dynamics of consolidated budgets revenues (to corresponding period of previous year, \%), number of regions. Compiled based on Rosstat data.

distribution did not differ from the previous precrisis years: most of those who lost their jobs did not apply for benefits, the amount of which remained low (RUB 1500-4500). The rapid increase in registered unemployment in spring 2020 is due to an institutional factor: an increase in benefits to the level of the subsistence minimum in regions and significant easing of the conditions for registration with employment services. In May 2020, the 2009 peak was passed and the histogram became closer to normal, as jobs were lost by those employed in the market services sector, the share of which is significant in the overwhelming majority of regions. Thus, if institutional conditions are not a barrier, registered unemployment reflects the impact of crises in the regions, and their distribution approaches normal.

Histograms based on the dynamics of budget indicators also reveal differences between the three crises. Obviously, the decline in regional budget revenues was the strongest in the acute phase of the coronavirus crisis, during the April quarantine period (Fig. 4). During the 2009 crisis, the recession was more localized geographically, but in the affected regions, it was quite strong. In 2015, there was no decline in budget revenues in the overwhelming majority of regions.
The differences are manifested in the receipts of underlying taxes and gratuitous aid from the federal budget. During the 2009 and 2020 crises, the main factor behind the drop in budget revenues was a sharp decline in profit tax revenues, the main payer of which are large businesses in export sectors. The global decline in demand for products during these crises was comparable, so the distribution histograms are similar: the more developed industrial regions suffered more. In April 2020, these were supplemented by federal cities due to the suspension of the market services sector. During the 2015 crisis, neither global nor domestic demand for industrial products declined as much; therefore, in most regions, the dynamics of profit tax was positive and the distribution was closer to normal.

The histograms of the distribution of regions according to the dynamics of PIT best reflect the features of each crisis. The landslide recession in April 2020 affected almost all regions. The 2009 dynamics had a wider range: from significant losses in the most affected industrial regions due to underemployment and layoffs to growth in all others. In 2015, PIT receipts grew in the overwhelming majority of regions, 
because wages in rubles continued to grow, from which this tax is mainly paid.

The histogram of the dynamics of transfers (gratuitous aid) to regional budgets well illustrates the differences in policies on the part of federal authorities. During the 2009 crisis and coronavirus crisis, assistance to regions was much greater than during the 2015 crisis, when budgets showed practically no revenue losses. The scale of regional budgets losses at the peak of the coronavirus crisis in April 2020 was greater than in January-August 2009; however, the distribution of regions by aid dynamics for both periods is comparable, while many regions received more in the 2009 crisis. It is clear that the data for April 2020 alone are insufficient to assess the level of support; additional transfers were allocated in May and will be allocated later. However, a conclusion suggests itself: the federal authorities have been late in responding to the shock drop in budget revenues, and there is a lag in assistance to regions.

\section{CONCLUSIONS}

The acute phase of the coronavirus crisis in Russia is due to economic (decreased demand) and institutional (quarantine restrictions) factors. According to statistics, four pain points can be distinguished.

The first is a sharp decline in consumption (retail and paid services) due to the introduction of quarantine, which hit the largest cities with a more developed service sector the hardest.

The second is a significant decline in industrial production due to deterioration in the global environment and domestic demand; it was maximum in regions with export specialization and a developed automotive industry.

The third is a rapid increase in the level of registered unemployment in the overwhelming majority of regions due to not only the crisis, but also institutional factors: an increase in the amount of unemployment benefits and easier registration of unemployed.

The fourth is the strong decline in budget revenues in more developed regions due to a drop in profit tax and PIT.

Obviously, the fifth pain point is the decline in household income, but it is still impossible to assess their dynamics in regions due to a lack of data.

Taking into account the incomplete recovery from the 2015 crisis, it can be assumed that the recovery growth of regions after the coronavirus crisis will be slow and stretch for several years.

Comparison of the three crises of the 2000s revealed their significant regional differences in the rate of the recession. The dynamics of the main indicators is due to the global and internal factors of the crisis, different risk zones, and duration of the decline. In 2009, the main risks were industrial recession in metallurgy and machinery-industry regions, increase in unemployment and underemployment, decrease in budget revenues in industrial regions due to the drop in profit tax; however, personal incomes and consumption were less affected. The 2015 crisis led to a widespread decline in household incomes, consumption, and investment (in terms of investment with the exception of Moscow and the main oil and gas producing regions), but unemployment rates remained practically unchanged. The 2020 coronavirus crisis was a landslide and accompanied by a decline in the widest range of indicators. Consumption of services and retail trade decreased the most, especially in the largest cities, due to the quarantine, industrial production in regions with export industries and developed automotive industry, as well as budget revenues in more developed regions.

In Russia, each crisis forms its own "geography of problems"; therefore, measures to support regions should take these features into account. Unfortunately, unlike the active policy by the federal authorities aimed at helping regions during the 2009 crisis, in subsequent crises, aid was either minimal (2015) or very late (2020).

\section{CONFLICT OF INTEREST}

The authors declare that they have no conflict of interest.

\section{REFERENCES}

1. Budgets. The virus in the regions: comments on government and business, Higher School of Economics, 2020. https://www.hse.ru/pubs/share/direct/document/373271455.pdf. Accessed June 15, 2020.

2. Grigor'ev, R.A., Kramin, M.V., Kramin, T.V., and Timiryasova, A.V., Disparity in income distribution and economic growth in Russian regions in post-crisis period, Ekon. Reg., 2015, no. 3, pp. 102-113.

3. Zubarevich, N.V., Overcoming the crisis: regional projection, Vopr. Ekon., 2012, no. 4, pp. 67-83.

4. Zubarevich, N.V. and Safronov, S.G., Territorial income disparity of the population in Russia and other large post-Soviet countries, Reg. Issled., 2014, no. 4, pp. 100-110.

5. Zubarevich, N.V., Regional projection of the new Russian crisis, Vopr. Ekon., 2015, no. 4, pp. 37-52.

6. Zubarevich, N.V., Makarentseva, A.O., and Mkrtchyan, N.V., Socioeconomic situation in Russian regions and demographic results of 2019, Ekon. Razvit. Ross., 2020, vol. 27, no. 4, pp. 73-87.

7. Zubarevich, N.V., Regional risks of a new crisis for employment and regional budgets, Monit. Ekon. Situatsii Ross., 2020, no. 7 (109). https://www.iep.ru/ru/monitoring/regionalnye-riski-novogo-krizisa-dlya-zanyatosti-i-byudzhetov-regionov.html.

8. Kuznetsova, O.V., Vulnerability of the structure of regional economies in crisis, Federalizm, 2020, no. 2, pp. 20-38. 
9. Monitoring sotsial'no-ekonomicheskogo polozheniya i samochuvstviya naseleniya (Monitoring of Socioeconomic Situation of Population), Moscow: Ross. Akad. Narodn. Khoz. Gos. Sluzhby, 2020.

10. Monit. Ekon. Situatsii Ross., 2020, no. 14 (116). https://www.iep.ru/ru/publikatcii/publication/monitoring-ekonomicheskoy-situatsii-v-rossii-14-116may-2020-g.html. Accessed June 10, 2020.

11. Nefedova, T.G. and Treivish, A.I., Raiony Rossii i drugikh evropeiskikh stran s perekhodnoi ekonomikoi (Regions of Russia and Other European Countries with Transitional Economics), Moscow: Vash Vybor, 1994.

12. Nefedova, T.G. and Treivish, A.I., The crisis in Russian regions, Ekon. Zhizn', 1996, no. 37.

13. Nefedova, T.G. and Treivish, A.I., "Strong" and "weak" cities of Russia, in Polyusa i tsentry rosta $v$ regional'nom razvitii (Poles and Centers of Growth in Regional Development), Moscow: Inst. Geogr., Ross. Akad. Nauk, 1998, pp. 157-167.
14. Nefedova, T.G. and Treivish, A.I., Crisis and intercrisis development of modern Russia in different geographic scales, Izv. Ross. Akad. Nauk, Ser. Geogr., 2009, no. 4, pp. 7-16.

15. Pishnyak, A., Korchagina, I., Gorina, E., and TerAkopov, S., Support of families with children during COVID-19 pandemic: Discussion paper no. 4, Higher School of Economics, 2020. https://www.hse.ru/data/2020/06/29/1610612279/ISP\%20HSE_COVID$19 \% 20$ and $\% 20$ Families $\% 20$ with $\% 20$ Child..ussion\%20Paper\%204_June\%2025\%202020_RUS.pdf. Accessed June 26, 2020.

16. Rossiya regionov: $v$ kakom sotsial'nom prostranstve my zhivem? (Russia of Regions: What is the Social Space Where We Live?), Zubarevich, N.V., Ed., Moscow Pomatur, 2005.

17. Economic and social consequences of coronavirus pandemic in Russia and in the world, Anal. Byull. Vys. Shk. Ekon., 2020, no. 4. https://www.hse.ru/mirror/pubs/share/370616519.pdf. Accessed June 27, 2020 . 